\title{
How do teachers teach mathematics and science in english?
}

\author{
Suharyadi \\ State University of Malang English Departement Faculty
}

\begin{abstract}
Teaching mathematics and science in English has been a hot topic in the academic amospheres such as at schools, universities, and research centers. Teaching mathematics and science in English, in this context, is the teachers' use of English as a medium of instruction in delivering the content subjects: mathematics, biology, chemsitry and physics. In particular, teachers use English in order to open classes/greet students, review previous topics, inform topic(s) to be learned, ask questions, answer questions, explain concepts, give directions, and do parting, all of which are embodied in words, phrases and sentences. However, these classroom activities might not be easily accomplished as teachers' English skills are not well prepared. Since they are not the English specialists, they likely use strategies in their classroom communication with their students. They use strategies in order to make their messages comprehensible to students. Their "language" (words, expressions, phrases, and sentences) should be simple and understandable so that students can figure out what is presented and taught easily. This paper is intended to report a case study on (1) types of communication strategies employed by the teachers in teaching mathematics, chemistry, and biology in English; and (2) why they use such kinds of communication strategies in teaching mathematics, chemistry, and biology in English. The data obtained from observations (through videotaping), interviews, and questionnaires indicate that the teachers deploy several communication strategies with different reasons in teaching.
\end{abstract}

Key words: English, Communication strategies

\section{Introduction}

How teachers teach mathematics and science in English as reflected in the title basically refers to the communication strategies used by teachers in teaching. They use the strategies as they feel and are aware that their English is not good and sufficient. They cannot speak English fluently and accurately. Their sentences are grammatically incorrect. A lot of mistakes or errors are easily noticable in their production. Their pronunciation is so obscured that other people (also students) who understand English misunderstand them. Occasionally, they do not use timely words or terms to address particular objects in the target language and content subjects. Several misspellings are unavoidable. These language barriers or communication obstacles may be harmful as they erode away the meaningful commmunication between teachers and students in the classroom.

In many references, the communication strategie(s) are always abbreviated CSs as a plural form and CS as a singular form to refer to literally any strategies teachers use to help them cope with classroom communication. In the context of L2 learning, CSs are usually refered to a process how learners, as non-native speakers, deal with second language learning. As learners are in the process of learning and are non-native speakers, they must have a limited repoitoire of vocabulary, correct drills of pronunciation and rules of the target language. These may result in a decline in communication. According to Ghaleb (2002), such a decline or gap can happen in communication because learners have a problem on form or accuracy of the language. In order to maintain the 
communication, he adds, learners then need to use CSs to reduce a gap. These CSs are deployed as learners recognize the mismatch between their linguistic resources and the commmunicative intentions. Thus, CSs are seen as the learners' efforts to communicate their messages, for example, their opinions, ideas, feelings, and so on, in a situation in which they have limited language skills and components.

In the research context, CSs are neither new comers nor something new. CSs have been prominent since 1970s. A lot of studies in the field have been carried out and a plenty of articles have been published worldwide. In general, there are two research contexts of CSs. First, CSs have been research targets conducted in schools or universities in which students as non-native speakers learn a second language. Second, CSs have been in the schools or universities where students as non-native speakers learn a foreign language (Ip \& Chan, 1985; Mak \& Siu, 1992; Marsh et al, 2000; Wannagat, 2007; Rabab'ah, 2005; Lafford, 2004). In these two contexts, learners mainly become the subjects of the research in which they use CSs in their communication and interaction.

However, studies on CSs which focus on teachers as the subjects have not been given a serious intention both in ESL and EFL contexts. Teachers, in this regard, are those who teach non English subjects such as mathematics, chemistry, and biology, physical education, geography, etc. in the classroom, in which English is used as a medium of instruction. They are non native speakers of English nor English specialists. They do not graduate from the English departments nor do they get English courses for preparation. English is not their L1 nor L2. English is a foreign language which can only be found and taught in English courses, schools, and universities.

This phenomonen is unique in the sense that teachers do not have good command in English to realize the classroom communication, yet they are required to do so, particularly to open the class, give instructions, explain the concepts, answer the questions, and close the class. Not only that, they are also expected to make their messages comprehensible to students. How teachers teach mathematics and science in English is then interesting to explore. In particular, teachers use their strategic competence in their teaching to make the communication run well. This paper is intended to report a case study on (1) what types of CSs employed by the teachers of mathematics, chemistry, and biology; and (2) why they use such kinds of CSs in teaching.

\section{Review of Literature \\ This section discusses the nature of CSs and taxonomies of CSs.}

\subsection{The Nature of CSs}

Historically, the term "communication strategy" was initially introduced by Selinker (1972:229) to refer to the strategy or way used by students in the L2 learning and communication, particularly to deal with language problems (e.g. a language deficit) they face when communicating their messages to other people. CSs were said to be one of the most important elements in the L2 learning process and, therefore, Selinker's work inspired other researchers to explore CSs in different contexts. Various definitions on CSs then appeared to provide fruitful perspectives and analyses. For example, Savignon (1972) used a different term "coping strategy" to refer to CSs in language teaching and testing. According to Lazarus (1982), coping is a part of a person's personal resources. It is expressed through all cognitive and behavioral efforts designed to respond to, diminish, reduce, minimize, control, dominate, tolerate or solve problems in stressing and emotionally negative situations brought about by external (the environment) or internal sources (the family) in a sociocultural context (Góngora, 2000). It entails managing and adjusting to said changes (Lazarus and Folkman, 1984).

Also, Tarone, Cohen and Dumas (1977:5) define CS as 'a systematic attempt by the learner to express or decode meaning in the target language, in situations where the appropriate systematic target language rules have not been formed'. Similarly, Corder (1983:16) states that CS is 'a systematic technique employed by a speaker to express his meaning when faced with some difficulty.' Besides, Poulisse (1993:22) contends that CSs are 'strategies which a language user employs in order to achieve his intended meaning on becoming aware of problems arising during the planning phase of an utterance due to his own linguistic shortcomings'. 
Furthermore, Faerch and Kasper (1983:36) say that CSs are 'potentially conscious plans for solving what to an individual presents itself as a problem in reaching a particular communicative goal'.

The above definitions show a similar aggreement among experts on CSs. CSs are basically strategies used by learners to overcome a gap in their communications. In particular, several points can be generated from the above difinitions. First, CSs are similar to the term "a solution of a problem" in any situations. A solution can mean a way out people use to cope with their problems in their daily life, for example, the problems related to personality, finacial, education, or health. A solution can also mean cures that people need when they are getting sick. In this context, CSs help learners "heal" their problems in communicating their meanings though they are linguistically and pragmatically insufficient.

Second, when learners use CSs, they are, in my point of view, usually aware of two things. First, they are aware that they have limited storage of vocabulary and rules of the target language. Second, they are aware that they need to use CSs because they still want to express their ideas, opinions, and feelings without being hindranced by their linguistic deficit. So, the point is that lack of the target language repetoire is not an obstacle for them to realize a communication. Third, CSs are commonly employed when learners learn a second language or a foreign language. In particular, CSs generally take place when learners speak in the target language. In this situation, learners usually cannot control their mind to talk. Sometimes, they do not think what to talk and do not know what words are appropriate to use and how the words are appropriately combined in sentences. Even, learners having good command in English still use CSs to deal with a communication gap. Indeed, it is different from that when learners write. They tend to have time to think of and use the appropriate words and rules to express their meanings.

In the Indonesian context, CSs can be then defined as strategies used by learners of English as a foreign language or a second language in order to express their ideas, opinions, and feelings or to communicate their intended meaning to other people in a situation in which they are linguistically and pragmatically not supported.
The word "learners" have two meanings. First, it refers to learners who learn English in the classroom in which English is a subject, for example, learners in high shools and universities. Second, it means teachers who informally learn English and use it for delivering the content subject, such as mathematics, chemistry, and biology. In this case, the teachers are those who teach those subjects and are required to use English as a medium of instruction.

\subsection{Taxonomies of CSs}

Taxonomies of typologies are systematic organizing structures for a range of events within a domain (Bialystok, 1990). The organizing principle can be that of spatial /temporal contiguity (leading to schematic structure) and principle of similarity (leading to categorical taxonomic structure). Since 1977, there are have been many taxonomies of CSs produced by different experts (see Tarone's Taxonomies (1977); Faerch and Kaspen's (1983); Bialystok's (1983); Paribakht's (1985); Willems' (1987); Bialystok's (1990); Nijmegen Group's (no year); Poulisse's (1993); and Dornyei and Scott's (1995). Most taxonomies proposed are organized by categorical taxonomic structure. This is the central organizing principle in science and philosophy. For the purpose of this study, Tarone's (1977) taxonomies of $\mathrm{Cs}$ are discussed.

Tarone classifies CSs into five types. They are avoidance, paraphrase, conscious transfer, appeal for assistance, and mime. The cases of avoidance strategies are interpreted by comparing content discrepancies between the two data sets, that of target language and that of native language. She then refines this strategy into topic avoidance and message abandonment. Topic avoidance implies that specific topics or words are avoided to the best ability of learners while message abandonment indicates that learners stumble into a topic that is too difficult and simply give up and go on to another.

Paraphrase is the rewording of the message in an alternative acceptable target language construction in situations where the appropriate form or construction is not known or not yet stable. She identifies further this strategy into three: approximation, circumlocution, and word coinage. Conscious transfer (later changes as borrowing) has two manifestations: literal translation and 
language switch. In this case, the learner borrows from any language s/he knows. Appeal for assistance is said to happen when the learner has consulted any source of authority, a native speaker, a dictionary, the researcher, or the person $s /$ he is speaking to. Mime includes all non-verbal accompaniments serving in the place of a missing target language word. Here, some concepts are easy to stimulate but other gestures are considerably less understood by a listener.

Tarone's taxonomy shows that it is developed based on the work on interlanguage production, especially those related to the empirical observation of studies of second language learners. It is proved to be a valuable basis for most studies in the area of CSs conducted in the future.In the context where the mathematics and science teachers use English in teaching, this taxonomy can be applied for the analysis.

\section{Method}

This study was conducted in the mathematics and sciences classes of SMA Negeri 3 Malang. These classes were taken because the teachers of these subjects are supposed to use the English language in the classroom. The subjects involved in the study were one mathematics teacher, one chemistry teacher, and one biology teacher. In order to gather data, the researcher utilized three techniques: observations, interviews and questionnaires. The observations were utilized to obtain the data concerninng the CSs employed by teachers. To make it easy, a video recorder was utilized to record all the teaching and learning process. Interviews were held to obtain some explanations of the following points. They are the percentage use of English in teaching, in what context the teacher uses English in teaching, the problems the teacher faces in using English to communicate the subject contents, the solutions they have to overcome the problem, the teacher's CSs used more frequently during the teaching and learning process, and the teacher's most effective CS used in teaching. The interviews were carried out directly after the observations. Interviews were used to support the findings from observations. Similar to interviews, questionnaires were also used to supplement the observation data. Questionnaires were distributed to students whose teachers were observed. They were constructed to get information whether students understood the way the teachers spoke and to obtain information concerning the most comprehensible teachers' utterances (therefore, the most effective CS) according to the students' point of view.

The data from observations, interviews, and questionnaires were then analyzed. In analyzing the data from observations, the followings steps were carried out. First, the researcher transcibed the video files to be written files by watching and listening to them for several times for comprehension and accuracy. The researcher jotted down all of the teachers' utterances and the students' utterances on pieces of paper regardless of weather they used English or not. Second, the researcher identified each teacher's utterance and student's utterance by categorizing them. Third, the teacher selected the categories which reflected the teachers'CSs in English. In order to facilitate the selection, the researcher used the taxonomies of CSs provided by Tarone (1977).

The data from interviews were analyzed in the followings steps. First, the researcher transcibed the audio files to be written files by listening to them for several times for comprehension and accuracy. The researcher jotted down all of the teachers' responses. Second, the researcher identified the responses and used them to support the findings from the observations. Meanwhile, the data from questionnaires were analyzed by following these steps. First, the researcher grouped the students' responses based on the types of questions used. There were two types of questions: open-ended questions and closed-ended questions. The students' responses of open-ended questions were clustered based on the questions given. The students' responses of closed-ended questions were tallied to calculate the percentage.

\section{Findings}

The data from observations, interviews, and questionnaires show that the teachers of mathematics, chemistry, and biology apply three types of CSs in teaching as shown in Table 1.

\begin{tabular}{cl}
\hline No. Subjects & Strategies \\
\hline Mathematics & Translation \\
Teacher & Code switching/code \\
\hline
\end{tabular}




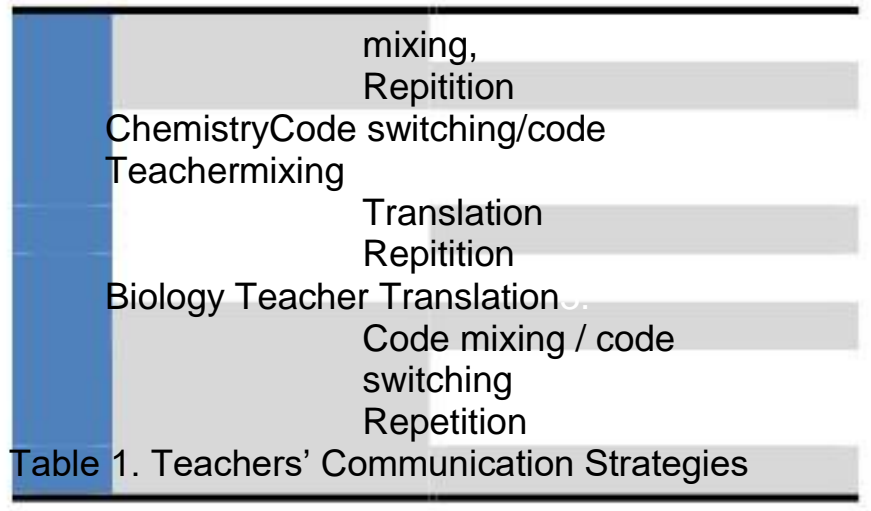

The strategies include translation, code switching/code mixing, and repitition. The three teachers used the same CSs but in different order.This order indicates the teachers' frequent uses of strategies to cope with language barriers in the classroom. The mathematics and biology teachers, for instance, tended to use translation more often than the others: code mixing / code switching and repition. The chemistry teacher, however, put code mixing / code switching as the main strategy followed by translation and repetition. The data also demonstrate that the teachers considered repitetion as the third one in helping them deliver meanings. It means that this strategy had the least frequent use in the classroom In order to picture out how each strategy was administered by the teachers, the following section is to devoted to explicating the relevant data.

\subsection{Translation}

All teachers availed translation in the classroom teaching. The mathematics and biology teachers mainly used it to help them teach the content subject, while the chemistry teacher made use of it as the second strategy after repitition. The following data depict the teachers of mathematics, chemistry and biology respectively in using the translation.

The data below describe how the mathematics teacher used translation in teaching.

\section{Data 1}

$\mathrm{T}$ (13) : You know function. A function $\mathrm{F}$ from a set $A$ to a set $B$ is an assignment of exactly one element of $B$ to each element of $A$.

T (14) :Jadifungsiituadalah pemetakanhimpunan A ke himpunan B tepat satu (1)elemen dari himpunan B. Himpunan A ke B itu memasangkan tepat satu ke himpunan $B$.

\section{Data 2}

$\mathrm{T}(174)$ : If the sample of coefficient of polynomial before zero. Jadi jika jumlah coefesiennya dari suku banyak itu nol, then equal one is root of the polynomial. Jadi jikka jumlah dari coefesien suku banyaknya itu nol, maka X sama dengan satu itu pasti akar dari polinomial tersebut.

Data 1 line 13 clearly indicate that the teacher explained the mathematical concept to the students about a function in English. In so doing, the teacher used the LCD to help her show the learning materials and explicate them. However, she did not produce her own English utterances in elaborating the concepts. Intead, she read the concepts written in English from the slides she had prepared. First, she read the English version, and was then followed by a translation in Bahasa Indonesia as shown in line 14. In this point, she translated her explanation into Indonesian completely.

Similar to data 1, the data 2 also show that the teacher used a translation strategy in communicating her message about the coefficient of polynomial. First, she said it in English "If the sample of coefficient of polynomial before zero", then she translated it into Indonesian "Jadi jika jumlah coefesiennya dari suku banyak itu nol”. Here, she translated the sentences entirely. However, in her own sentence, she did not put an "is" after the word "polynomial". It seemed she had a problem with it. But, it did not distract the students' understanding. After that, she also uttered her second message in English "then equal one is root of the polynomial". Her second English sentence was grammatically accepted. In translating the second utterance, however, the teacher tried to repeat her first Indonesian translation to be included in the second Indonesian translation "Jadi jika jumlah dari coefesien suku banyaknya itu nol, maka $X$ sama dengan satu itu pasti akar dari polinomial tersebut".

The mathematics teacher's use of translation is also supported with interview data. The teacher states that she used the translation in the following ways. She explained the learning 
materials in English and was followed with Indonesian translations. When the teacher explained the concepts in English, and the students' face showed confusion, she usually immediately used a translation. To her, the translation was helpful and the most effective because it could facilitate the students' learning, especially to understand the concepts spoken in English. With the translation, the students could directly know the meanings. The students did not need to translate the language into Indonesian to understand the messages.

The data of the questionnaire for students shows that the translation strategy was placed in the first rank by the students. About 12 (44.4\%) of 27 students stated that the translation was the most helpful one in making them understand the concepts. They argued that they could understand the concepts more easily when translated.

Similarly, the chemistry teacher also used translation but as the second strategy. The data are presented in the following.

\section{Data 1}

T (145) : What do the producers use to measure the $\mathrm{Ph}$ ?

Sf1 (146) : Apa mom?

T (147) : Pakai apa di situ mengukur

Phnya?

SS (148) : (silence)

$\mathrm{T}$ (149) : To measure Ph untuk

mendapatkan data ini? To get this data, what do they use?

SS (150) : (silence)

paper?=

$\mathrm{T}(151)$ : Would they use litmus

$$
\text { SS (152) : =no }
$$

In data 1, it is clear that the teacher gave a question related to $\mathrm{Ph}$. Initially, the teacher revealed the question in English "What do the producers use to measure the Ph?", but the students did not figure it out. Secondly, she modified her question. She translated the question into Indonesian. She said "Pakai apa di situ mengukur Phnya?. Still, there was no response from the students. Thirdly, the teacher modified her question for the second time with the hope that students could give the answer. Here, she used a more specific and detail question with translation "to measure Ph untuk mendapatkan data ini? To get this data, what do they use?. Again, the students did not give any response to the question. The next teacher's strategy was she still used another question In English, but she mentioned the word "litmus paper" to encourage students to have an answer. In fact, the students could respond it by saying "no".

According to the teacher's interview, in general students' English is good. She believed that the students understand her questions or statements in English. Yet, their lack of understanding of the chemical concept that led to confusion. She added that she did not use the strategy very much in teaching and learning process because she thought that it did not educate students in learning and even the translation could hinder the students' understanding. The interview shows that she almost never used translation in teaching. She would translate her messages into Indonesian in case of emergency. According to her, the problem was not the students' English was bad, but the students were not familiar with the terms used in Chemistry. Therefore, she used other strategies that the students were familiar with. However, the teacher said that the translation strategy was basically effective, efficient, and faster. It was good to underpin the students' concepts. But it did not educate students. That's why, she almost never applied it her teaching and learning. She used it only a particular circumstance, for example, when the students did not give any responses to the teacher's question. She would translate it. This fact is also supported by the fact the there were only three students or $18.75 \%$ considering the translation which assisted them in learning. This describes that the translation did not really help most of the students understand the learning materials.

The biology teacher also employed translation as shown in the following data.

Data 1

$\mathrm{T}$ (32) : We will compare, we will compare the difference between eukaryote and prokaryote cell. And then after that we will compare animal and plant cell. What is the difference and what is the similarity. And we also discuss your course study one by one the organil "organelle", organel, organel that you 
found in plant cell or plant cell

and animal cell. Kita akan lihat satu

persatu.Setelahkita

membedakan antara plant and animal, kita akan

Tihat

organelnya aman yang ada di

tumbuhan, mana yang ada di hewan.

Data 2

$T(29)$ : And the second classification of

sugar is based on the size. The size of $C$ skeleton, skeleton atom. Jadi yang

kedua pengelompokan gula dua berdasarkan rangka atom $\mathrm{C}$ nya.

We know that there are 3 atoms. Carbonic atom called triosse.

As shown in data 1 line 32, the teacher firstly gave information about what the students would do with the concepts of biology such as eukaryote and prokaryote cells and animal and plant cells in English. The teacher then translated her explanation into Indonesian as indicated in the underlined sentences. The translation was applied to make students understand the teacher's messages. The students were hoped to attain clearer information. In this context, there was no so called "language problem" faced by the teacher.

In data 2, the interaction occurred when the teacher explained the classification of sugar. She said that "And the second classification of sugar is based on the size, the size of $C$ skeleton, Skeleton atom". The teacher then provided the full translation version of her sentence. It can be seen in the underlined sentence. The translation was basically to help students figure out the intended meaning.

This finding is also supported by the interview result showing that the teacher used the translation to make the students understand the concepts easily. She added that the translation was the most effective strategy as it could accelerate and facilitate the students' understanding and did not need a lot of time. Furthermore, she stated that supposing that full Indonesian was used in teaching biology, there would no problem in communication the messages. Therefore, she thought that the translation would help students learn easier.

Based on the questionnaire given to the 16 students in the Biology class where the teacher was teaching, it is found that, among others strategies, the translation was the second facilitative strategy. About $25 \%$ (4 students) stated that the translation could help them understand the concepts better.

\subsection{Code switching/Code Mixing}

The three teachers also employ code switching/code mixing in teaching. The data of the mathematics teacher's use of code switching/code mixing is presented below.

Data 1

SX-f (87) : Dua

$\mathrm{T}(88)$ : By using the (1) remainder

theorem, $F$ negative one equals two. Dan jika dibagi $x$ min 3 sisanya tujuh.

$F$ three equals seven. Suku banyak $G X$

tiga. dibagi $X$ plus satu, sisanya

From the data line 88 , it is clear that the teacher did a code switching. She code switched from English to Indonesian in different sentences but related when she was explaining the ways to overcome the question. Firstly, she said "By using the (1) remainder theorem, $F$ negative one equals two. She then continued "Dan jika dibagi $x$ min 3 sisanya tujuh" and so on. In this context, the teacher had no problem with her language. Her sentences were correct. Besides, the teacher did a code switching only for the sake of the students' better comprehension on the concepts.

\section{Data 2}

$\mathrm{T}(51)$ : she wrote the question number nine on the white board and said\}. Suppose the remainder is (1) AX plus $B$, dibagi $X$ min satu berarti kan Fx, gitu kan, sama dengan nol. A plus $B$ equals zero and then firstly equation.

The data above also indicate the teacher's code switching strategy in communication. She code switched the explanation from English into Indonesian. First, she said "Suppose the remainder is (1) AX plus B", and was followed with "dibagi $X$ min satu berarti kan Fx, gitu kan, sama dengan nol". The teacher then said another English sentence "A plus $B$ equals zero and then firstly equation". The samples indicate that the teacher did face a barrier in communication. Her main 
intention was that she wanted students to understand the messages easily.

This finding is confirmed with the interview data. the teacher says that she used code switching/mixing in teaching mathematics in two ways: English to Indonesian and Indonesian to English. But, English to Indonesian mostly occurred. According to the teacher, code switching/mixing was used when she was in emergency, meaning that she did not know the words or terms in English when explaining the topics. She just immediately switched her language from English to Indonesian when she could not find the equivalence in English. She did not want to think in a longer time. She further added that the students were fine with my code switching/mixing.

In terms of effectiveness, the teacher claimed that code switching /mixing was the second effective strategy in making her messages compressible to the students. This strategy was also helpful when the teacher did not know the words in English. In line with this, the questionnairedatashowthatcode switching/mixing was considered the second helpful strategy. Around 8 (29.62\%) of 27 students stated that code switching/mixing was facilitative in understanding the teacher's explanations, questions, or directions.

Besides the mathematics teacher, the chemistry teacher also used code switching/code mixing in teaching as shown below.

\section{Data 1}

$\mathrm{T}(68)$ : Yes, if you put too much

fertilizer, what happen the plant?

SS (69) : Osmosis

T (70) : Airnya keluar dari, dari akarnya, airnya keluar. Mestinya kita berharap airnya masuk (1) osmosis, tapi

kalau the concentration in the soil too high, the concentration here is too high, it would become reverse osmosis, kebalikannya. So if you are using too much fertilizer not only harmful or reverse osmosis tapi juga become acidic.

In the extract above, it is seen that the teacher used code switching in communicating her messages, particularly when she was explaining about osmosis. Firstly, she used Indonesian to define osmosis and what happens with osmosis. She said "Airnya keluar dari, dari akarnya, airnya keluar. Mestinya kita berharap airnya masuk (1) osmosis" Then, she continued elaborating. She told "tapi kalau the concentration in the soil too high, the concentration here is too high, it would become reverse osmosis, kebalikannya. So if you are using too much fertilizer not only harmful or reverse osmosis tapi juga become acidic". From this context, it is identified that the function of the teacher's code switching was to explain a term or give information related to Chemistry. The term might be difficult for students to understand. That's why the teacher tried to make her sentences comprehensible to students.

Data 2

$\mathrm{T}$ (71) : Acidic oil bisa ditanamin?= SS (72) : =ndak $\mathrm{T}(73)$ : No

$\mathrm{T}(74)$ : Just like this one the teacher showed a paper to thestudents\}, number six ini ada $\mathrm{Ph}$ yang paling cocok untuk menamam tanaman ini. You have daffodil, violet etc. This is the best $\mathrm{Ph}$ for

planting these flowers. Beda-beda ya tiap tanaman. Jadi sebelum kita menanam kita harus cek the $\mathrm{Ph}$.

Just like in data 1, data 2 also describe the teacher's strategy in making her sentences understandable.Sheimplementedcode switching/mixing when asking a question and explaining. In asking a question, she uttered "acidic oil bisa ditanam?" This comprises two languages in one sentence: English (acidic oil) and Indonesian (bisa ditanam). In addition, she also used cod switching and mixing in giving an explanation in two languages. For example, she said "Just like this, number six ada $\mathrm{Ph}$ yang paling cocok untuk menamam tanaman ini" etc.

The interview data indicate that the teacher used this strategy in order to make her messages easy to understand. However, she seldom used this strategy. Even, she put this strategy number 6 out of 7. It was most probably due to the fact that her English is better than the Mathematics teacher. Her TOEFL score is 570. From English learning experiences, the Chemistry teacher has been learning English since elementary school. The 
interview result shows that she once stayed in Australia for study. Recently, she has also attended an international workshop in Malaysia as a part of her teaching requirement. In her real teaching, she used more English than Indonesian. She gave more English exposure in teaching and learning process.

In terms of the effectiveness, however, the teacher argued that code switching/ code mixing was one of the ineffective strategies to be used in the Chemistry class as she should spend more time in repeating the words, phrases, or sentences to make the students understand. This teacher's view seems not in line with the students' perception. The questionnaire data show that there were 7 students or $47.75 \%$ considered the code switching and code mixing as a facilitative strategy in their learning. It means that almost half of the students were helped when the teacher used code switching and code mixing in teaching and learning process.

The biology teacher also used this strategy in order to make her messages easy to understand as shown below.

\section{Data 1}

T (71) : One, two, three, four, five, five daily test. Mungkin yang ini gak. After that we have final test. Terus (1) karena kalian aksel (1) jadi nanti all materials we will explain, we will discuss

in the class. So there are some materials we must do at home.

In line 71 , it is seen that the teacher used code switching in communicating her messages for several times. For example, first, she used English "One, two, three, four, five, five daily test". Then she switched to Indonesian "Mungkin yang ini gak". After that she used English again "After that we have final test" and so on.

\section{Data 2}

$\mathrm{T}(57):$ Ok, .... And there are six $\mathrm{C}$ atoms, atom, satu, dua, tiga, empat, lima, enam. Kemudian the carbonyl group, the carbonyl group is on the first $\mathrm{C}$. Ini $\mathrm{O}$ double bone. C. First C.... Jadinya adalah seperti ini. Seperti yang ini. This is the first $C$, (1) atom $C$ yang

sebelah sini.

Just like in data 1 , data 2 also describe the teacher's strategy in making her sentences understandable.Sheimplementedcode switching/mixing when elaborating the form chain of glucose. For several times, she code switched her sentences. The interview result indicates that the teacher very often used code switching/mixing in teaching and learning, especially when the students did not understand the instruction. Besides, the teacher used this strategy when she forgot what to say in English, especially when explaining the materials.

In terms of effectiveness, the teacher views that code switching/mixing was the second effective strategy to make the students understand her messages. Similar to translation, code switching/mixing did not waste time. For the students, code switching/mixing was also a facilitative strategy to make them understand the concepts easily. Around 37\% (6 students) say that code switching/mixing helped them in learning.

\subsection{Repetition}

The third strategy is repetition. Three teachers used this strategy in their teaching so that the students understood her messages as shown below.

Data 1

$\mathrm{T}$ (174) : Ok. There is number (2) nine to the power of three over two?

Sf1 (175) : Ha?

Sf2 (176) : Ha?

Sf3 (177): Nine?

Sf2 (178) : Apa bu?

$\mathrm{T}$ (179) : There is numbe:r, nine to the power of three over two?

Sf1 (180): Three over two.

Sf2 (181) : Sembilan

Sf3 (182) : Sembilan

The data show that the mathematic teacher gave a mathematical question to the students to be calculated. The teacher said it verbally and students should listen to it carefully to understand. 
As shown in line 174, the teacher said "Ok. There is number (2) nine to the power of three over two?" However, the teacher's question was not easily figured out by the students. Basically, the sentence was grammatically correct and not confusing. It might be that the students were not familiar with the expression "...power of three over two". It is clear that the students said "ha?", "nine", "and "apa bu" indicating their confusion. Having known this problem, the teacher then initiated to repeat the question. She uttered the question for the second time "There is number (2) nine to the power of three over two". The first and repeated utterances were the same. There was no any single word changed to make students understand more easily. In fact, after the teacher's repetition, the students could find the value of the question. They said "sembilan" as the answer. It is also obvious that the students needed two processes to grasp the entire meanings. First, they should understand the language. Second, they should understand the concept. The students required longer time for it.

\section{Data 2}

$\mathrm{T}(266)$ : In this numbe:r, the prime number multiply five between two and ten? SS (267) : Between two and ten?

$\mathrm{T}(268)$ : The prime number multiply five between two and ten?

SS (269) : Dua pangkat lima

The data above also indicate the teacher's repetition of her question. Initially, the teacher read the question "the prime number multiply five between two and ten?" However, the students did not catch the meaning of the question completely. They then just mentioned "between two and ten?" a part of the question to verify. Afterwards, the teacher repeated her question for the second time. In this repetition, the teacher used the same question without changing any words. It is clear that the students were able to respond to the teacher's question in Indonesian "dua pangkat lima".

The interview data reflect that the teacher utilized a repetition in teaching mathematics. She repeated her words in the sentences. The repetition, according to her, served three functions. First, it was to give an emphasis that English should be used by the students in the classroom. Second, it was to give feed backs or corrections to the students' responses. Third, it was to assure that the students understood her messages. However, repetition was not effective because it took long time. The teacher would not use Indonesian when her first and second repeated sentences were not well understood by the students.

In line with this, the questionnaire data indicate that the repetition was in the third helpful strategy. Around 5 (18.5\%) of 27 students stated that the repetition done by the teacher could facilitate their understanding on the teacher's explanations, questions, and directions.

For the chemistry teacher, repetition is also important to communicate her messages. The teacher repeated her utterances so that the students understood her messages as shown in the data below.

Data 1

$T(100)$ : Please pass it to your friends in front of you.

$T(101)$ : Pass your paper to your friend in front of you.

SX-f (102) : All?

$\mathrm{T}(103)$ : No, Only the last page please. Only the last page

$T(107)$ : Ok. Only the last page.

$\mathrm{T}(108)$ : Pass to the front

$T(111): Y a$, pass it to the front

$\mathrm{T}(112)$ : Pass it to the front

The data above indicate the teacher's strategy in communication. She repeated the sentences "Please pass it to your friends in front of you" and "Only the last page please" for several times. The purpose of this repetition was to give more emphasis on the intended messages so that the students got used to and understood the meaning. Concretely, from the repetition, the teacher wanted the students to do only the last page of the worksheet and pass the work to the front. In this case, there was no the so called language deficit. Both the teacher and students did not have a problem with language. The teacher could state her message and the students could understand it.

Data 2 conjugate acid why? Karane basenya? 
SX-m (233) : Menghilang

$T$ (234): Basenya enggak hilang,

basenya terserap ya

T (235): Get, accept $<>$ H plus $<1 />$

SS (236) : <>H plus $<1 />$

$\mathrm{T}$ (237) : Maka yang tadinya base

menjadi conjugatenya acid karena gain Hplus, gain $\mathrm{H}$ plus, yang tadinya

base menjadi acid because they gain $\mathrm{H}$ plus.

In the above data, the teacher repeated the word "gain" to refer to getting or receiving something for three times. In this context, the teacher wanted to give a more focus on why something (base) became acid. She expected the students to know the concept of gaining $\mathrm{H}$ plus by repeating the word. The data above reflect that there were two functions of the repetition. The first was when the teacher wanted to make an emphasis on the particular words. The second is for comprehending the concepts. This is in line with result of interview stating that the teacher repeated her words or utterances for two functions. First, it was to make students get used to new words. Second, the students were hoped to figure out the words and the concepts.

In terms of effective CSs in the classroom, the teacher stated that repetition was the second most effective way to make students understand the concepts. She added that the intended repetition was not just repeating the words or utterances all the time, but the words should be used continuously and consistently. She believed that the students could grasp the meanings. The questionnaire data show that the teacher's repetition also facilitated the students' learning. But, there were only three or $18.75 \%$ of the students said so. It means that most of the students were not really assisted with this strategy.

The repetition also occured when the biology teacher taught. She repeated her utterances so that the students understood her messages as shown below.

\section{Data 1}

$\mathrm{T}(76)$ : Ok, this is your first

handout in this semester.

T\&SS (77) : \{they were talking about

the school project in 5 minutes\}

$\mathrm{T}(78)$ : Ok, open page (1) one,

page one, page one, (1) page molecules.

The data above line 78 show how the repetition process occurred. In line 76 , the teacher just distributed the handout to students. He told the students "Ok, this is your first handout in this semester" The next interaction was the teacher gave an instruction to the students. Here, the teacher repeated her instruction for several times. She said "Ok, open page one, page one, page one, page one about biology molecules" In this context, the repeated instruction was meant to give an emphasis with the hope that the students could understand the direction more clearly.

Data 2

$T$ (22) : That's general formula of carbohydrate. And (1) the there are three, (1) there are three kinds of carbohydrates:

monosaccharide, disaccharide, and polysaccharide.... Ok, nah based on (1) the location of carbonic group, based on the location of carbonic group there are two types of sugars (2) carbonyl. There are two types of sugar. Based on the place of carbonyl group, there are two types of sugar.

The data 2 also reflect the teacher's repetition in teaching biology. In this case, the teacher repeated her sentences for several times when explaining the location of carbonic group. She said "Ok, nah based on the location of carbonic group, based on the location of carbonic group, there are two types of sugars carbonyl. There are two types of sugar. Based on the place of carbonyl group, there are two types of sugar" The repetition was intended to make students familiar with the concepts and remember them easily.

These two functions of teacher's repetition are in line the teacher's interview stating the teacher's repetition serves two functions. First, it is to make students get used to new words. Second, the students are hoped to figure out the words and the concepts easily. The questionnaire for the students indicates that 19\% (3 students) state that the teacher's repetition could also help students understand the lesson easily. It means that the 
repetition did not help most of the students yet in their learning.

\section{Discussions}

This section presents the discussions of the findings on the CSs employed by the mathematics, chemistry, and biology teachers comprehensively. In particular, the research findings are discussed by comparing them with the relevant theories and the results of other relevant studies. As the data show that the mathematics teacher employed three CSs in English comprising translation, code switching/code mixing, and repetition. The chemistry teacher also utilized the same strategies coveringcodeswitching/codeswitching, translation, and repetition. Similarly, the biology teacher applied the strategies of translation, code switching/code mixing, and repetition.

The mathematics teacher's English is not sufficient, yet her use of strategies does not always refer to the her attempts to communicate her meanings when faced with some difficulties or problems. But, she also deals with a situation in which the students do not have previous knowledge when the teacher explains the concepts in English. The chemistry teacher using these strategies is not due to the fact that her English competence is low. Rather, the students do not understand the basic concepts of chemistry. So, she translates, codes switch or repeat her sentences or words in order that students comprehend the meanings. Similarly, the biology teacher applies the strategies not only because she has a language problem, but also she knows that students lack the comprehension on concepts. In other words, the use of communication strategies does not merely reflect the teachers' language deficit. The students' lack of understanding on concepts may also trigger this situation. This finding is significantly in contradiction with several experts stating that the CSs are used because the teachers do not know the target language in communication.

For example, Corder (1981) argues that CS is a systematic technique employed by the speaker to express his/her meaning when faced with some difficulty. 'Difficulty', in this definition refers to speaker's inadequate command of language used in interaction. He argues that CSs essentially have to do with the relation between end and means. Ideally, in a native speaker, the relationship is in balance. S/he always possesses the linguistic means to express the messages $\mathrm{s} / \mathrm{he}$ wants to communicate. However, it is not in balance in L2 setting. Sometimes a learner wants to get the meaning across, but linguistic means to express it does not permit him/her to do so successfully. In this situation, only two options are open to him/her. $\mathrm{S} /$ he can either adjust his/her ends to his/her means (message adjustment or risk -avoidance) or to attempt to increase his/her resources to realize his/her ends (resources expansion or risk-running or success-oriented strategy). Another theory is by Tarone (1983) defining CSs as mutual attempts of two interlocutors to agree on a meaning in situations where requisite meaning structure (both linguistics and sociolinguistic) do not seem to be shared. She gives three criterions for CSs use. They are a desire to communicate a meaning $X$, means to communicate the meaning $X$ is not available, and an attempt (a) to avoid to communicate the meaning $X$, or (b) to find alternative ways to communicate meaning $X$.

From the facts above, it is inferred that the CSs used do not always reflect the teacher's linguistic problem, particularly in communicating the messages in English. But, they are used because of the students' lack understanding of the learning materials. The students do not have enough prior knowledge on the topics.

Besides, there is no considerable different among the teachers in terms of the strategies, yet the order of the strategies seems to show the frequent use and effectiveness. The data show that the teachers utilize the translation as the first more frequently used strategy in teaching and learning process. It gives benefits to the teacher and students. According to Fish (2003), the use of translation can bring many benefits for both teachers as well as learners. Translation provides learners with the practice and skills necessary to communicate accurately, meaningfully and appropriately. Through translation activities, teachers can promote interaction among learners since they involve the negotiation of multiple possibilities of form and meaning, and translation can help learners to interpret, negotiate and express meaning from different perspectives, according to the context and its different interpretive communities.

The second strategy is code switching/code mixing. Code switching is switching or alternating between two or more languages. In this context, 
code switching or code mixing strategy is used when the teacher is in emergency, meaning that she does not know the words or terms in English when explaining the topic. In this case, code switching or code mixing assists the teacher to keep the communication going with the students. It is in line with an idea proposed by Akindele and Letsoela (2001) and Ramahobo and Orr (1993) stating that code-switching is a form of compensatory strategy for some linguistic deficiency in the teachers.

The teachers also claim that students can understand the subject contents easily when code switching and code mixing are applied. It is in line with a study conducted by Ndayipfukamiye (1994) which shows that code switching is a more successful strategy used by the teachers in teaching. In addition, Baker and Jacobson cited in Cook (1991) state that code-switching can be developed as a teaching method which gets teachers to balance the use of the two languages at specific points within a lesson, for instance, switching to L1 when a new concept is met, or to praise, to quote someone, to emphasize a point, or to tell off a misbehaving member of the class.

The next strategy is the repetition. It is applied to make sure the students understand the instructions, questions, information, or material given. This finding supported the studies done by Hamayan and Tucker (1980), Wesche and Ready (1985), and Mannon (1986) showing that the teachers' repetition is effective for improving the students' comprehension. In addition, by using the strategy, the teachers could also provide the students with more chances to process the information given by the teachers or to follow the teachers' models.

In terms of the effectiveness, there are three strategies which are facilitative to the teachers and students and effective to be used in the classroom. They are translation, code switching/mixing, and repetition. These strategies can overcome the communication gaps between the teachers and students in the classroom. The translation strategy is fast, meaning that the students can immediately know the meanings of the teachers' explanations. The repetition facilitates the students in knowing the concepts or terms more deeply. The code switching enables the teacher to keep on talking. She can explain the topics without being hindered with the lack of her target language. These findings, however, are not in accordance with the findings by some experts. For example, Ellis (1986) found that "achievement" strategies, such as paraphrase and word coinage are more effective than "reduction" strategies. Also, Chen (1990) observed that "linguistically-based" strategies, such as the use of synonyms, tend to be more effective in conveying information than conceptual strategies, such as saying what an item is used for, or referring to folk traditions that are associated with it.

Furthermore, the three CSs found in the current study are different from those by Tarone's (1983) taxonomy which cover five types of communication strategies. They are avoidance, paraphrase, conscious transfer, appeal for assistance, and mime. However, compared with Donyei (1995) study, it seems that the current findings are mostly similar. Donyei (1995) divides communication strategies into twelve types. They are message abandonment, topic avoidance, circumlocution, approximation, use of all-purpose words, word coinage, use of nonlinguistic means, literal translation, foreignizing, code switching, appeal for help, and use of fillers/hesitation devices. The current study also shows the strategies including translation, and code switching/mixing. However, the repetition strategy is not identified in Donyei (1995).

In addition, the present findings are also partly similar to some studies, for example, Hasanuddin (2001) found that Indonesian people who used English for communication in academic employed fourteen types of CSs such as interlingual or intralingual transfer, repetition, code switching, grammatical simplification, paraphrasing, cooperative/appeal for help, restructuring,messageabandonment, communication filler, exemplification, retrieval, topic change, non-linguistic, and using formulaic expression. Also, Syafei (1994) found that the fourth year students of English Department at the University of Muria Kudus used some CSs such as approximation, word coinage, circumlocution, literal translation, language switch, appeal for assistance, message abandonment, topic avoidance, and combination types.

The different findings stated above are assumed due to different contexts. The context of the current finding was not in English classes, but 
in the mathematics, chemistry, and biology classes where the teacherx used English (as a foreign language) in delivering the subject contents. In this case, the teachers are not English specialists, mathematics and science teachers who are supposed to use English in the classroom. On the other hand, the findings by Ellis and Chen were in ESL/EFL classes in which the teachers taught English to the students.

\section{Conclusions}

Based on the findings and discussions, it is concluded that the mathematics teacher employs three strategies to make the messages comprehensible to the students in teaching and learning process. They are translation, code switching and code mixing, and repetition. It is concluded that the use of the strategies do not always reflect the teacher's language deficit, but they are used because the students lack the concepts of the subject matters. Besides, it is concluded that the translation, code switching and code mixing, repetition are effective and facilitative strategies to make the students understand the learning materials easily. But, the translation strategy is the most effective of all strategies used in the classroom.

In the chemistry class, the teacher uses three strategies to make the students understand the concepts easily. They are code switching and code mixing, translation, and repetition. Again, the teacher uses the CSs are not always because of the linguistics barrier, but the teacher's way to make the messages more comprehensible. Besides, it is concluded that code switching and code mixing, translation, repetition are useful to be used in the classroom. They are also facilitative in making the messages more comprehensible to the students. From the strategies, however, the translation is the most effective to facilitate the students' learning.

In the biology class, it is also inferred that the strategies of code switching and code mixing, translation, and repetition are used. Similar to the other classes, these strategies are important to apply in the classroom. They are good for the teacher to be able to communicate the messages comprehensively. From the strategies above, the translation strategy is the most effective because it can accelerate and facilitate the students understanding of the concepts.

\section{REFERENCES}

[1] Akindele, D and Letsoela, M. 2001. Code Switching at Leshoto Secondary and High Schools Lesson and Its Effects on Teaching and Learning. BOLESWA Educational Research Journal, (18), 83-100.

[2] Bialystok, E. 1983. Some Factors in the Selection and Strategies. In C. Faerch \& G. Kasper (eds), Strategies in interlanguage communication. London: Longman.

Bialystok, E. 1990. Communication Strategies: A Psychological

[3] Analysis of Second-Language Use. Oxford: Basil Blackwell. Breiteneder, Pitzl, Majewski, and Klimpfinger, 2006. Voice

[4] Recording - Methodological Challenges in the Compilation of a Corpus of Spoken EL. Nordic Journal of English Studies. 5 (2): 161 188).

Canale, M. and Swain, M. 1980: Theoretical bases of communicative approaches to second language teaching and testing. Applied

[5] Linguistics 1, 147 .

Chen, G.M. 1990. Foundations of Intercultural Communication. Neddham Heights, M.A:Ally and Bacon

[6] Cook, V., 1991. Second Language Learning and Language Teaching Melbourne: Hodder Headline Group.

[7] Corder, S. P.. 1981. Error Analysis and Interlanguage. Oxford: OUP Corder, S. P. 1983. Strategies of communication. In C. Faerch \& G. Kasper (eds), Strategies in interlanguage communication. London:

[8] Longman.

[9] Del, Ma M. M, V and Garces, Pilar C. 1996. Communicative Functions of Repitition in Classroom Interaction. Resla, (II), 129-143 Depdiknas, 2007. Sistem Penyelenggaraan Sekolah Bertaraf

[10] Internasional (SBI) untuk Pendidikan Dasar dan Menengah. Jakarta: Depdiknas.

Do"rnyei, Z. and Scott, M. 1995: Communication strategies in a

[11] second language: definitions and taxonomies. Review article. Language Learning 47, 173_210.

Dornyei, Z. 1995. The Teachability of Communication Strategies.

[12] TESOL QUARTERLY (29), 55-85

Dulay, H. Burt, M., and Krashen, S. 1982. Language Two. New York: Oxford University Press.

[13] Ellis, R.1986. Understanding Second Language Acquisition. Oxford: OUP.

Faersch, C. and Kasper, G., editors, 1983. Strategies in

[14] Interlanguage Communication. London: Longman. Fish, Stanley. 2003. Is There a Text in This Class? The Authority of

[15] Interpretative Communities. USA: Harvard University Press. Hamayan, E.V. and Tuckher, G.R. 1980. Language Input in the

[16] Bilingual Classroom and its Relationship to Second Language Achievement. Tesol Quarterly. (14), 453-468.

Hasanuddin, 2001. Strategies in Interlanguage Communication Used

[17] by Indonesian Speakers of English. Unpublished Dissertation. Malang: Post Graduate Program at State University of Malang.

[18] Mannon, T.M. 1986. Teacher Talk: A Comparison of a Teacher's Speech to Native and Non-Native Speakers. Unpublished MA (TESL) Thesis. Los Angeles: University of California,.

[19] Ndayipfukamiye, L. 1994. Code Switching in Burundi Primary Classrooms. In Teaching and Research Language in African Classrooms. Editor C.M.Rubaguma. Clevedon: Multilingual Matters. Paribakht, T. 1985. Strategic Competence and Language Proficiency.

[20] Applied Linguistics, 6,132-46.

Poulisse, N. 1993: A theoretical account of lexical communication strategies. In Schreuder, R. and Weltens, B., editors, The bilingual

[21] lexicon, Amsterdam: John Benjamins, 157 89.

Ramahobo, L. and Orr, J. 1993. Primary Education and Language Teaching in Botswana. Common Treads of Practice: Teaching English to Children Around the World. Alexandria: TESOL.

[22] Savignon, S.J. 1972. Communicative Competence: An Experiment in Foreign Language Teaching. Philadelphia: The Center for

[23] Curriculum Development

Selinker, L. 1972. Language Transfer. In General Linguistics. 9 (2):67-92.

[24] Syafei, M. 1994. A Study in the Use of Communication Strategies at the English Department of the University of Muria Kudus. Unpublished Dissertation. Malang: Post Graduate Program at State University of Malang

[25] Tarone, E. 1977. Conscious Communication Strategies in Interlanguage. In H.D Brown, C.A.Yorio, \& R.C. Crymco (Eds.). On TESOL '77. Washington, D.C.: TESOL, 194-203.
[26] 
[29] Tarone, E. 1983. Some Thoughts on the Notion of Communication Strategy. TESOL Quarterly. 15 (3): 285-295.

[30] Tarone, E., Cohen, A.D., \& Dumas, G. 1976. A Closer Look at Some Interlanguage Terminology: a Framework for Communication Strategies. In Faerah, C. \& Casper, G. (Eds.), Strategies in Interlanguage Communication. London: Longman.

Varadi, T. 1973. Strategies of Target Language Learner

[31] Communication: Message Adjustment. IRAL, 18, 59-71 Willems, G. (1987). Communication Strategies and Their

[32] Significance in Foreign LanguageTeaching. System, 15 (3), pp. $351-364$.

\section{Biography}

Suharyadi ${ }^{*}$ is a faculty member at the English Department Faculty of Letters State University of Malang. Currently, he is a doctorate student at State University of Malang, majoring in English

language teaching. His interests include general linguistics, systemic functional linguistics, genre-based approaches, English language teaching, bilingual education, writing, and second language acquisition. 